This work is licensed under Creative Commons Attribution 4.0 International (CC BY 4.0). [http://creativecommons.org/licenses/by/4.0/]

\title{
Glosa do wyroku Sądu Apelacyjnego w Katowicach z dnia 5 lipca 2018 r.
}

Eugenia Tereszczenko | Uniwersytet Gdański https://orcid.org/0000-0002-3423-9357

Słowa kluczowe: powierzenie pracy, dobra osobiste pracownik work assignment, personal rights, employee

\section{Streszczenie}

Jednym z rozważanych wątków w niniejszej glosie była ocena zgodności z prawem powierzenia innej pracy pracownikowi na podstawie art. $42 \S 4$ k.p. Tylko przy łącznym spełnieniu wszystkich czterech przesłanek z art. $42 \S 4$ k.p. można stwierdzić, iż przeniesienie do innej pracy jest prawidłowe i odpowiada obecnemu stanu prawnemu. W okolicznościach danego stanu faktycznego przeniesienie powódki do innej pracy było wbrew przepisom Kodeksu pracy, ponieważ co najmniej dwie z wymaganych przesłanek nie były spełnione.

Drugim wątkiem niniejszej pracy było zastanowienie się, czy doszło w tym stanie faktycznym do naruszenia dóbr osobistych powódki. W wyniku przeprowadzonej analizy przedstawionych okoliczności należy stwierdzić, iż dobra osobiste powódki zostały naruszone. W szczególności została naruszona godność pracownicza powódki. Pojęcie godności pracowniczej zostało doprecyzowane na gruncie doktryny prawa pracy i orzecznictwa.

\section{Gloss to the verdict of the Court of Appeal in Katowice of July 5, 2018} (Summary)

One of the considered issues in this opinion was legality of transferring an employee to another job pursuant to art. $42 \S 4$ k.p. Only when all four conditions of art. $42 \S 4$ of the Labour Code are fulfilled, it can be stated that the transfer to another job is legitimate. In the circumstances of the case, the transfer of the Plaintiff to another job was against the provisions of the Labor Code, because at least two of the required conditions were not met.

Furthermore in this gloss aims to consider whether there was a breach of the Plaintiff's personal rights. As a result of the analysis of the presented circumstances, it should be stated that the personal rights of the Plaintiff were violated. In particular, the employee dignity's of the was breached. The concept of employee dignity is clarified by the author on the basis of the doctrine of labor law and case law. 


\section{Tezy}

1. Powierzenie pracownikowi, który przez długi okres zajmował stanowisko specjalisty, a później i starszego specjalisty do spraw kadr, uzyskał tytuł magistra na kierunku zarządzanie w zakresie zarządzania zasobami ludzkimi i rozszerzał swoją wiedzę na licznych kursach tematycznych, pracy niewymagającej jakichkolwiek specjalnych kwalifikacji zawodowych, bez jawnych uzasadnionych potrzeb pracodawcy na podstawie art. 42 § 4 ustawy z 26 czerwca 1974 r. - Kodeks pracy (t.j. Dz. U. z 2018 r., poz. 907 ze zm.) (dalej: k.p.), nie było zgodne z prawem.

2. Strona pozwana naruszyła dobra osobiste powódki w postaci godności pracowniczej, między innymi poprzez:

- powierzenie powódce innej pracy, bez uzasadnionych potrzeb, następujące od razu po zwróceniu się do Prezesa pracodawcy z niewygodnym pytaniem, które można traktować jako karę za takie zachowanie;

- traktowanie powódki jako zbędnego pracownika poprzez usadowienie przy stoliku okolicznościowym oraz poprzez powierzenie pracy, przy której nie są potrzebne ani wieloletnie doświadczenie powódki, ani jej dotychczasowe kwalifikacje;

- wymuszenie czekania przez powódkę na spotkanie z Prezesem w Wielki Czwartek, który również był dniem urodzin powódki.

\section{Stan faktyczny}

Powódka J.S. w pozwie skierowanym do Sądu Rejonowego w Katowicach przeciwko Fabryce (...) S.A. w K. między innymi domagała się zasądzenia od pozwanej przeproszenia powódki poprzez wywieszenie w widocznym dotychczasowym miejscu pracy powódki oświadczenia o określonej treści.

Z pozwu wynikało, że w spornym okresie powódka była zatrudniona u pozwanej w pełnym wymiarze czasu pracy na stanowisku starszego specjalisty do spraw kadr.

W okresie od dnia 1 lutego 2016 r. do dnia 29 marca 2016 r. pozwana zachowywała się w stosunku do powódki niewłaściwie. Początek naruszeń związany był z artykułowaniem przez powódkę oceny dotyczącej niewłaściwego i niezasadnego ustalenia warunków związanych z zatrudnieniem jednego z pracowników pozwanej. Powódka podała, że kiedy w dniu 23 marca 2016 r. pisemnie zwróciła się do Prezesa pozwanej z prośbą o zweryfikowanie zatrudnienia w dziale pod względem otrzymywanego wynagrodzenia za pracę i anulowanie dysproporcji, dnia następnego powódka została przeniesiona na okres do dnia 31 marca 2016 r. do pracy w dziale logistyki i magazynów.

Po przeniesieniu do działu logistyki i magazynów powódka usadowiona została przy stoliku okolicznościowym, który znajdował się w miejscu widocznym dla pozostałych pracowników Spółki. Po skierowaniu powódki na nowe stanowisko nie otrzymała ona żadnej możliwości wykonywania pracy na rzecz pozwanej Spółki, dopiero 
wyraźnie przez nią skierowane prośby do kierownika działu spowodowały, że polecono jej wykonywanie archiwizacji zamówień w celu odzyskania starych segregatorów.

Po rozpoznaniu sprawy sąd pierwszej instancji nakazał pozwanej złożenie powódce pisemnego oświadczenia o treści, w której pozwana przeprasza powódkę za wszystkie zachowania naruszające jej godność i dobre imię w miejscu pracy, za jej lekceważenie i dyskredytację jako wieloletniego pracownika oraz zamieszczenie tego oświadczenia $w$ siedzibie pozwanej $w$ widocznym miejscu w terminie 14 dni od daty uprawomocnienia się wyroku.

Od tego wyroku przez stronę pozwaną była złożona apelacja, którą sąd apelacyjny oddalił.

\section{Ocena stanowiska Sądu Apelacyjnego w Katowicach}

W glosowanym wyroku Sąd Apelacyjny w Katowicach nie rozstrzyga o zasadności rozwiązania umowy o pracy z powódką, bowiem sama powódka nie kwestionuje tego faktu. Z tego względu autor niniejszej glosy również nie będzie brał pod uwagę w swoich rozważaniach wątpliwości, które miały miejsce przy rozwiązaniu umowy o pracy w danym stanie faktycznym.

Legalna definicja pracodawcy została zawarta w art. 3 k.p., zgodnie z którą pracodawcą jest każdy (osoba fizyczna, osoba prawna, jednostka organizacyjna nieposiadająca osobowości prawnej), kto zatrudnia pracowników. W doktrynie wyróżnia się cztery rodzaje ryzyka, które ciążą na pracodawcy w związku z zatrudnieniem przez niego pracowników: ryzyko ekonomiczne, techniczne, socjalne i osobowe.

Pierwsze z nich, ryzyko ekonomiczne, polega na tym, iż pracodawca musi wypłacać pracownikom wynagrodzenie i inne świadczenia wynikające ze stosunku pracy niezależnie od efektów ekonomicznych prowadzonej działalności (Stelina 2018: 13). Drugie zawiera w sobie obowiązek wypłacania pracownikowi wynagrodzenia między innymi w czasie przestoju z przyczyn techniczno-organizacyjnych (art. 81 k.p.). Ryzyko socjalne odnosi się do obowiązku pracodawcy wypłacania wynagrodzenia nawet w razie nieobecności pracowników z przyczyn choroby, opieki nad dzieckiem i innych wymienionych w Kodeksie pracy. Z kolei czwarte polega na tym, że pracodawca jest obciążony skutkami niezawinionych, a także zawinionych przez pracownika działań wyrządzających pracodawcy szkodę (Stelina 2018: 13).

Skutkiem ponoszenia takiego obszernego ryzyka przez pracodawcę było wprowadzenie do Kodeksu pracy między innymi instytucji powierzenia pracownikowi innej pracy, która została ukształtowana w art. $42 \S 4$ k.p. Ta instytucja została utworzona w celu ułatwienia pracodawcy organizacji i kierowania jego zakładem pracy w sposób bardziej efektywny i elastyczny w sytuacjach wyjątkowych. 
Zgodnie z zawartą w art. $42 \S 4$ k.p. regulacją pracodawca ma prawo bez wypowiedzenia dotychczasowych warunków pracy lub płacy powierzyć pracownikowi, w przypadkach uzasadnionych potrzebami pracodawcy, innej pracy niż określona w umowie o pracę na okres nieprzekraczający trzech miesięcy w roku kalendarzowym, jeżeli nie powoduje to obniżenia wynagrodzenia i odpowiada kwalifikacjom pracownika. Inną pracą w rozumieniu art. $42 \S 4$ k.p. jest praca odmiennego rodzaju niż określona w umowie o pracę, a nie praca rodzajowo ta sama, lecz świadczona na innym stanowisku (Florek 2017: 316). Pracodawca może bowiem zawsze przenieść pracownika z określonego stanowiska na inne, jeżeli nie pociąga to za sobą zmiany rodzaju pracy określonej w umowie czy innych istotnych warunków pracy (Florek 2017: 316).

Jak wynika z powyższego przepisu, aby pracodawca mógł skorzystać z instytucji powierzenia pracownikowi innej pracy niż ta, która została określona w umowie o pracę, muszą być spełnione następujące przesłanki:

- powierzenie innej pracy może mieć miejsce w przypadkach uzasadnionych potrzebami pracodawcy;

- praca może być powierzona na okres nieprzekraczający 3 miesięcy w roku kalendarzowym;

- powierzenie innej pracy nie może powodować obniżenia wynagrodzenia;

- praca powierzona musi odpowiadać kwalifikacjom pracownika.

Należy podkreślić, iż wszystkie wymienione wyżej przesłanki muszą być spełnione łącznie, i gdyby chociaż jednej z nich brakowało, takie przeniesienie pracownika należałoby uznać za niezgodne z prawem.

Znaczenie klauzuli generalnej „uzasadnionych potrzeb pracodawcy” zależy od okoliczności każdego konkretnego przypadku (Rycak 2018: 258). Zgodnie z orzecznictwem Sądu Najwyższego „uzasadnione potrzeby pracodawcy" należy rozumieć jako potrzeby zakładu pracy jako całości, a nie tylko jednostki (komórki) organizacyjnej zakładu pracy, do pracy, w której pracownik został skierowany (wyrok SN z 08.08.1979, I PR 55/79).

Pracownik ma prawo kwestionować twierdzenie, że powierzenie mu innej pracy w trybie art. $42 \S 4$ k.p. jest podyktowane uzasadnionymi potrzebami pracodawcy (Florek 2017: 318). Jak słusznie zauważył Sąd Apelacyjny w Katowicach, ciężar dowodu, że dobro osobiste zostało zagrożone lub naruszone, spoczywa na osobie poszukującej ochrony prawnej z mocy art. 24 ustawy z dnia 23 kwietnia 1964 r. - Kodeks cywilny (t.j. Dz. U. z 2018 r., poz. 1025) (dalej: k.c.), natomiast na sprawcy owego zagrożenia lub naruszenia spoczywa obowiązek wykazania, iż jego działanie nie było bezprawne (wyrok SA w Katowicach z 05.07.2017, III APa 22/18). To stwierdzenie jest zgodne $z$ art. 6 k.c., który wyraźnie stwierdza, iż ciężar udowodnienia faktu spoczywa na osobie, która z faktu tego wywodzi skutki prawne. Z powyższego wynika, iż ciężar dowodu, że powierzenie innej pracy powódce w danych okolicznościach było zgodne z prawem, spoczywa na pozwanej. 
W ślad za Sądem Apelacyjnym w Katowicach należy stwierdzić, że pozwanej nie udało się udowodnić w sposób niebudzący wątpliwości jakichkolwiek uzasadnionych potrzeb dla przeniesienia powódki na inne stanowisko pracy. Za tym przemawiają zeznania kierownika działu logistyki, jak również i fakt, iż powódce początkowo nie przydzielono obowiązków pracowniczych, i dopiero gdy zwróciła się z prośbą o wyznaczenie zadań, wskazano, że ma „odzyskiwać segregatory” (wyrok SA w Katowicach z 05.07.2017, III APa 22/18).

Drugą przesłanką, która wymaga wyjaśnienia dla oceny działania pozwanej na podstawie danego stanu faktycznego, są wymogi dotyczące kwalifikacji pracownika. Z przepisu nie wynika, czy mają to być kwalifikacje wykorzystywane do świadczenia pracy umówionej, czy też inne kwalifikacje, które pracownik posiada (Rycak 2018: 258). Zagadnienie to jest sporne w nauce prawa pracy, ponieważ część autorów uważa, że w grę wchodzą jakiekolwiek kwalifikacje, które pracownik posiada, część z kolei, że tylko te, które pracownik wykorzystuje do pracy umówionej (Rycak 2018: 258-259). Tak Zbigniew Góral uważa, iż nie może to być praca, która w znacznym stopniu odróżnia się od pracy dotychczas wykonywanej, nawet jeżeli pracownik posiada do jej wykonywania wystarczające kwalifikacje (Góral 2018: 372).

Razem z Sądem Najwyższym należy zauważyć, że pracą odpowiednią do kwalifikacji pracownika jest praca, która ich nie przekracza, ale też przy której te kwalifikacje znajdą zastosowanie, choć niekoniecznie w pełnym zakresie (wyrok SN z 05.02.1998, I PKN 515/97).

Należy podkreślić, że w każdym razie zmiana treści umowy o pracę na podstawie art. 42 § 4 k.p. nie może prowadzić do wykonywania przez pracownika pracy, do której potrzebne są znacznie niższe kwalifikacje, ponieważ może to prowadzić do naruszenia godności pracownika i zbyt daleko modyfikuje uzgodnienia poczynione w dniu zawarcia umowy (Rycak 2018: 259). Wyraźnym przykładem takiego poniżającego traktowania w wyniku zastosowania instytucji powierzenia innej pracy będzie powierzenie odwołanemu prezesowi zarządu spółki pracy niewymagającej wysokich kwalifikacji, wykonywanej na hali produkcyjnej pomiędzy pracownikami fizycznymi, gdy takie powierzenie niesie znamiona „intencjonalnego, świadomego i natężonego złą wolą działania zmierzającego do poniżenia i zdyskredytowania pracownika" (Góral 2018: 372).

W związku z powyższymi dywagacjami autor niniejszej glosy dochodzi do wniosku, że powierzenie innej pracy $w$ danym stanie faktycznym powódce nie odpowiada wymogom podniesionym w art. 42 § 4 k.p., więc stanowi akt bezprawnego zachowania pozwanej w stosunku do powódki. Powódka przez długi okres zajmowała stanowisko specjalisty, a później i starszego specjalisty do spraw kadr, uzyskała tytuł magistra na kierunku zarządzanie w zakresie zarządzania zasobami ludzkimi i rozszerzała swoją wiedzę z tego zakresu na licznych kursach tematycznych. Natomiast powierzona jej praca w dziale logistyki i magazynów, bez jawnych uzasadnionych potrzeb 
pozwanej, nie wymagała jakichkolwiek specjalnych kwalifikacji z zakresu posiadanych przez powódkę. Ten wniosek jest w pełni zgodny ze stanowiskiem Sądu Apelacyjnego w Katowicach wyrażonym w glosowanym wyroku.

Przechodząc do rozważań dotyczących naruszenia dóbr osobistych powódki w postaci dobrego imienia i godności przez powierzenie pracy w warunkach nieodpowiadającym wymogom art. 42 § 4 k.p., słusznie będzie w ślad za Sądem Apelacyjnym w Katowicach odwołać się do źródeł ochrony dóbr osobistych w Polsce i do samego pojęcia dobra osobistego, żeby prześledzić rozwój tej ochrony na gruncie prawnym.

Pojęcie dóbr osobistych odnosi się do cielesnej i duchowej natury człowieka, są one z człowiekiem nieodłącznie związane i wobec tego niezbywalne (Panowicz-Lipska 2018: 170). W literaturze akcentuje się, iż dóbr osobistych nie da się wycenić w pieniądzu, co nadaje im cechę dóbr niematerialnych (Panowicz-Lipska 2018: 171).

Konstytucja Rzeczypospolitej Polskiej z dnia 2 kwietnia 1997 r. (Dz. U. Nr 78, poz. 483) w art. 30 stwierdza, że przyrodzona i niezbywalna godność człowieka stanowi źródło wolności i praw człowieka i obywatela. Jest ona nienaruszalna, a jej poszanowanie i ochrona jest obowiązkiem władz publicznych. Zgodnie z art. 47 Konstytucji RP każdy ma prawo do ochrony prawnej życia prywatnego, rodzinnego, czci i dobrego imienia oraz do decydowania o swoim życiu osobistym.

Te postulaty między innymi znalazły odzwierciedlenie w przepisach Kodeksu cywilnego oraz Kodeksu pracy. Tak art. 23 k.c. zawiera otwarty katalog dóbr osobistych, wśród których znajduje się w szczególności cześć człowieka, które pozostają pod ochroną prawa cywilnego niezależnie od ochrony przewidzianej w innych przepisach.

Z kolei Kodeks pracy w art. $11^{1}$ nakazuje pracodawcy szanować godność i inne dobra osobiste pracownika. Dany przepis był dodany do Kodeksu pracy poprzez jego nowelizację z 2 lutego 1996 r., stanowiąc przełom w dotychczasowej prawnej ochronie dóbr niematerialnych pracownika (Perdeus 2018: 103), ponieważ po raz pierwszy wyraźnie na piśmie wprowadził obowiązek szanowania po stronie pracodawcy godności i innych dóbr osobistych pracownika. Poszanowanie godności pracownika powinno być interpretowane jako nieczynienie niczego, co godziłoby w jego godność. Pracodawcy nie wolno wykorzystywać swej przewagi na rynku pracy i pomiatać pracownikami, którzy w obawie przed zwolnieniami z pracy tracą poczucie własnej wartości i godzą się na poniżające traktowanie (Ochrona dóbr i godności pracownika, b.d.).

Pomimo skutecznego instrumentu ochrony dóbr osobistych każdej osoby, w tym i pracownika, w Kodeksie cywilnym, wprowadzenie danego uregulowania na gruncie Kodeksu pracy nie wydaje się zbędne. Podporządkowanie, które jest charakterystycznym elementem stosunku pracy oraz różne instytucje prawa pracy mające na celu wspomaganie pracodawcy w kierowaniu zespołem i organizacją procesu funkcjonowania przedsiębiorstwa, mogą niekiedy być nadużywane przez pracodawcę i prowadzić do naruszenia dóbr osobistych pracownika. Podobny przypadek nadużycia 
instytucji powierzenia innej pracy pracownikowi z art. $42 \S 4$ k.p. miał miejsce w przypadku danej sprawy.

W stanie faktycznym glosowanego wyroku powódka została przeniesiona na okres do dnia 31 marca 2016 r. do pracy w innym dziale. Od chwili zawiadomienia o przeniesieniu powódka nie miała możliwości zabrania nawet stanowiących jej własność przedmiotów znajdujących się w biurku. Po przeniesieniu do innego miejsca pracy powódka usadowiona została przy stoliku okolicznościowym, który znajdował się w miejscu widocznym dla pozostałych pracowników Spółki. Pracownicy ci z zaskoczeniem podchodzili do powódki, z niedowierzaniem wypytując, co było przyczyną takiej decyzji. Powódka nie otrzymała żadnej możliwości wykonywania pracy na rzecz pozwanej Spółki, dopiero wyraźnie przez nią skierowane prośby do kierownika działu spowodowały, że polecono jej wykonywanie archiwizacji zamówień w celu odzyskania starych segregatorów. Również znajomi męża powódki, pracującego w innej spółce w okolicy, pytali go o sytuację powódki w pracy. W związku z powyższym powódka poczuła, iż jej dobra osobiste w postaci dobrego imienia, godności i godności pracowniczej, polegającej na traktowaniu jej jako pracownika niezbędnego, zostały naruszone.

Orzecznictwo i głos doktryny, wyjaśniając pojęcie czci, zajmują jednolite stanowisko, które znalazło odzwierciedlenie w wyroku Sądu Najwyższego z dnia 8 maja 2014 r. (wyrok SN z 08.05.2014,V CSK 361/13). Sąd Najwyższy zauważył, iż powszechnie wyróżnia się dwa przejawy dobra osobistego, jakim jest cześć człowieka: cześć zewnętrzną (dobre imię) oraz cześć wewnętrzną (godność osobistą) (wyrok SN z 08.05.2014, V CSK 361/13). Czcią zewnętrzną w rozumieniu Sądu Najwyższego będzie „opinia, którą o danej osobie mają inni, a cześć wewnętrzna, to poczucie osoby o swojej wartości: oczekiwanie przez nią szacunku od innych" (wyrok SN z 08.05.2014, V CSK 361/13). Przy czym pojęcia czci, dobrego imienia, dobrej sławy odnoszą się do każdej dziedziny życia osobistego, zawodowego, społecznego (wyrok SN z 08.10.1987, II CR 269/87).

Naruszenie czci zewnętrznej (dobrego imienia) polega na pomówieniu danej osoby o takie postępowanie lub właściwości, które mogą ją poniżyć w opinii publicznej lub narażać na utratę zaufania potrzebnego do zajmowania określonego stanowiska, wykonywaniu zawodu lub innej działalności (Panowicz-Lipska 2018: 177). W stanie faktycznym glosowanego wyroku nie wystąpiło pomówienie w sposób jawny, ponieważ ze strony pozwanej nie było jakichkolwiek sformułowań, które by w sposób obraźliwy oddziaływały na powódkę. Natomiast miały miejsce takie zachowania pozwanej, które należy odnieść do działań, które udaremniają dobre imię powódki jako pracownicy.

Zdaniem autora niniejszej glosy, zwłaszcza na użytek podobnych przypadków, w piśmiennictwie została podjęta próba wyodrębnienia dobra osobistego w postaci „godności pracowniczej", rozumianej jako poczucie własnej wartości danej osoby opartej na pozytywnej wobec niej opinii jako o pracowniku (Panowicz-Lipska 2018: 178). Zachowanie pracodawcy $\mathrm{w}$ danym stanie faktycznym niejednokrotnie naruszało tak rozumiane dobro osobiste. Wskazać można tu na następujące zachowanie pracodawcy: 
- powierzenie powódce innej pracy bez uzasadnionych potrzeb następujące od razu po zwróceniu do Prezesa pracodawcy z niewygodnym pytaniem, które można traktować jako karę za takie zachowanie;

- traktowanie powódki jako zbędnego pracownika poprzez usadowienie przy stoliku okolicznościowym oraz poprzez powierzenie pracy, przy której nie są potrzebne ani wieloletnie doświadczenie powódki, ani jej dotychczasowe kwalifikacje;

- wymuszenie czekania przez powódkę na spotkanie z Prezesem w Wielki Czwartek, który również był dniem urodzin powódki.

Takie działanie pracodawcy godzi w naruszenie poczucia wartości danej osoby jako respektowanego i potrzebnego w zespole pracownika, czyli w godność pracowniczą.

Ponadto takie zachowanie pozwanej narusza także cześć wewnętrzną powódki (godność osobistą), która doznaje uszczerbku w razie znieważenia, polegającego na ubliżeniu komuś, ośmieszeniu, okazywaniu pogardy, upokorzeniu (Panowicz-Lipska 2018: 177). Nie budzi wątpliwości, iż takie traktowanie człowieka może zostać przyczyną upokorzenia, bowiem ze stanu faktycznego wynika, że znajdowanie się powódki w warunkach nietypowych było widoczne dla reszty zakładu pracy, a nawet dla kolegów męża spoza miejsca pracy powódki.

W związku z powyższym należy zgodzić się z rozumowaniem sądu Apelacyjnego w Katowicach i przyznać fakt naruszenia dóbr osobistych powódki, a mianowicie naruszenia godności pracowniczej.

\section{Zakończenie}

Jednym z rozważanych wątków w niniejszej glosie była ocena zgodności z prawem powierzenia innej pracy pracownikowi na podstawie art. $42 \S 4$ k.p. Zgodnie z przeprowadzoną analizą należy stwierdzić, że tylko przy łącznym spełnieniu wszystkich czterech przesłanek z art. $42 \S 4$ k.p. można uznać przeniesienie do innej pracy za prawidłowe i odpowiadające obecnemu stanowi prawnemu. W glosowanym wyroku słusznie zauważono, że co najmniej dwie z wymaganych przesłanek nie były spełnione, w związku z czym autor niniejszej glosy popiera stanowisko Sądu Apelacyjnego w Katowicach i uważa, iż w okolicznościach danego stanu faktycznego przeniesienie powódki do innej pracy było sprzeczne z przepisami Kodeksu pracy.

Drugim z analizowanych zagadnień było naruszenie dóbr osobistych powódki. Autor glosy doszedł do wniosku, że dobra osobiste powódki zostały naruszone. W szczególności została naruszona godność pracownicza powódki. Pojęcie godności pracowniczej zostało doprecyzowane na gruncie doktryny prawa pracy i orzecznictwa.

Taki wniosek również jest zgodny z opinią Sądu Apelacyjnego w Katowicach. 


\section{Bibliografia}

\section{Literatura:}

Florek L., 2017 [w:] L. Florek (red.), Kodeks pracy. Komentarz, Warszawa.

Góral Z., 2018 [w:] K.W. Baran (red.), Kodeks pracy. Komentarz, Warszawa.

Ochrona dóbr i godności pracownika, b.d., http://www.anteris.net.pl/index.php/panel-antydyskryminacyjny/22-ochrona-godnosci-i-dobr osobistych-pracownika\#ftnref4 [dostęp: 30.05.2019].

Panowicz-Lipska J., 2018 [w:] M. Gutowski (red.), Kodeks cywilny. Komentarz. Art. 1-353, t. I, Warszawa. Perdeus W., 2018 [w:] K.W. Baran (red.), Kodeks pracy. Komentarz, Warszawa.

Rycak A., 2018, Zmiana treści umownego stosunku pracy [w:] J. Stelina (red.), Prawo pracy, Rozdział VII, Warszawa.

Stelina J., 2018, Pojęcie, przedmiot, systematyka i funkcje prawa pracy [w:] J. Stelina (red.), Prawo pracy, Rozdział I, Warszawa.

\section{Akty prawne:}

Ustawa z dnia 23 kwietnia 1964 r. - Kodeks cywilny, t.j. Dz. U. z 2018 r., poz. 1025 ze zm.

Ustawa z dnia 26 czerwca 1974 r. - Kodeks pracy, t.j. Dz. U. z 2018 r. poz. 907 ze zm.

Konstytucja Rzeczypospolitej Polskiej z dnia 2 kwietnia 1997 r., w Dz. U. Nr 78, poz. 483 ze zm.

\section{Orzecznictwo:}

Wyrok Sądu Najwyższego z dnia 8 sierpnia 1979 r., I PR 55/79, OSNC z 1980 r., Nr 2, poz. 30.

Wyrok Sądu Najwyższego z dnia 8 października 1987 r., II CR 269/87, OSNCP z 1989 r., Nr 4, poz. 66. Wyrok Sądu Najwyższego z dnia 5 lutego 1998 r., I PKN 515/97 , OSNC z 1999 r., Nr 2, poz. 46.

Wyrok Sądu Najwyższego z dnia 8 maja 2014 r., V CSK 361/13, LEX 1491264.

Wyrok Sądu Apelacyjnego w Katowicach z dnia 5 lipca 2017 r., III APa 22/18, LEX 2533629.

\section{Biogram}

Eugenia Tereszczenko - studentka Wydziału Prawa i Administracji Uniwersytetu Gdańskiego. Zainteresowania: prawo pracy, prawo prywatne międzynarodowe. 